\title{
心臟に関する $\mathrm{MeSH}$ 用語の体系的学習
}

\author{
一目でみる心臟の $\mathrm{MeSH}$ 用語
}

\section{Systematic Study of MeSH Terms Regarding the Heart _-Pictorial Explanation of MeSH Heart Terms -}

\author{
堀江幸司 \\ 東京女子医科大学図書館
}

Horie, K. : Systematic Study of MeSH Terms Regarding the Heart-Pictorial Explanation of MeSH Heart Terms-. Igaku Toshokan 30(2): 119-133, 1983.

Medical Subject Headings (MeSH) was first published in 1960 by the National Library of Medicine in the USA is a medical terminology thesaurus which has been revised and published every year since 1963 as the Part II issue of the January edition of Index Medicus. Terms used in this MeSH are controlled vocabularies; descriptors, and are also used for (1) making the index for Index Medicus, (2) searching MEDLARS file and (3) cataloging books, serials and audiovisual materials. The author describes a fourth purpose, other than these primary uses, for MeSH terms, namely, obtaining fundamental medical knowledge by librarians. In the previous article, the effectiveness of systematic study of MeSH terms was described, and concrete examples were given using the MeSH terms of digestive system. This time the author studied MeSH as a thesaurus taking up some terms as examples from MeSH terms of the heart, according to such publication as "Technical Notes."

\section{I.はじめに}

Medical Subject Headings ${ }^{1)}$ (以下 MeSH という) は, 米国国立医学図書館 (National Library of Medicine, 以下 NLM という) が 1960 年に創刊し, 1963 年 から Index Medicus 1 月号の pt. 2 として毎年改訂発 行している医学用語シソーラスである。 ${ }^{233}$

この MeSH で使用されている用語は, 統制された用 語 (controlled vocabullary; descriptor, 以下 $\mathrm{MeSH}$ 用語という)であり, (1) Index Medicusの索引作成 (2) MEDLARS ファイルの検索 (3) NLMの図書拈よ び視聴覚資料の目録, に使用されている。これらの $\mathrm{MeSH}$ 用語の本来の使用目的のほかに, 著者は, $\mathrm{MeSH}$ 用語の第 4 の使用目的として, 図書館員が基礎 的な医学知識を得る手段としての利用を考えている。 以前に, $\mathrm{MeSH} の$ 系統別・体系的学習の有効性につ いて述べ, 5)その具体的な実例を消化器系の MeSH 用 語で示したことがあった。 ${ }^{6)}$ 今回は，心臟に関する

* Koji HORIE : Tokyo Women's Medical College Library, 10 Kawadacho, Ichigaya, Shinjuku-ku, Tokyo 162, Japan. (昭和 58 年 4 月 25 日 受理)
$\mathrm{MeSH}$ 用語のうち, Technical Notes ${ }^{7)}$ 等にそっていく つかを取り上げ，シソーラスとしての観点から検討し た。(表 1 , 図 1 )

\section{II. 心臓の解剖学的 MeSH 用語}

\section{1. 心臟と心筋}

心臓 (HEART) と心筋 (MYOCARDIUM) (H) $^{\text {(H) }}$ 用語は，しばしば同義語（準同義語）的に使われるこ とがあるが，ポンプとしての観点で心臟をみた場合 (heart as pump）にはHEARTをままた組織として の観点で心臓をみた場合（the heart as tissue）には

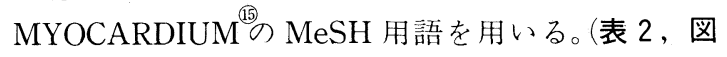
2)

\section{2. 心臓 (HEART) の形容詞形}

$\mathrm{MeSH}$ 用語としての心臓 (HEART) の形容詞形 (adjective form) はCARDIACであり, cardial は CARDIA (噴門)の形容詞形として用いられる。(実際 には, CARDIALのついた MeSH 用語はない)この 点, Dorland では, ${ }^{899110)}$ Cardiac を 1. pertaining to the heart (心臓の) 2. pertaining to the cardia (噴門 
の：食道に接近した胃の部分の）としている点に注意 を要する。

\section{3. 胎児心臓}

心臟の下位概念として, 胎児心臓 (FETAL HEART) の MeSH用語がある。このFETAL HEART という MeSH 用語は, 哺乳動物の胎児心臟 についてのみ用いられ，ひよこ胚の心臟 (Chick embryo heart）については, CHICK EMBRYO+ HEART/embryology の MeSH 用語を用いる。

胎児心臓には卵円孔（Foramen ovale）があり，胎 生時に重要な血行路をなすが, MeSH 用語では，この FORAMEN OVALEを心臟中隔（HEART SEPTUM $)^{2}$ の同義語（準同義語）とみなしている。

また，FETAL HEARTの下位概念に DUCTUS ARTERIOSIS (動脈管) があり，この動脈管は胎児循 環において肺動脈と大動脈弓とを交通するものだが， MeSH では脈管に分類せずに心臟の一部としている。

\section{4. 心房と心室}

心臟（HEART）には 4つの部屋（four chambers） がある。右心房 (right atrium)，右心室（right ventricule), 左心房 (left atrium) および左心室 (left ventricule)である。解剖学的には，心臟は上記のよう に4つの部屋に区別されるが，MeSH 用語では心房 (HEART ATRIUM) $^{1}$ と心室 (HEART VENTRICULE) ${ }^{(9)}$ とに区別し, 左右 (left half, right half) には区別していない。

また, 右心房と左心房は心房中隔, 右心室と左心室 は心室中隔でしきられているが，MeSH 用語では，心 臓中隔 (HEART SEPTUM) ${ }^{2}$ としている。1963 年ま では, HEART SEPTUM, ATRIAL および HEART SEPTUM, VENTRICULARの MeSH 用語があっ た。(図 2)

\section{5。灾臟の弁}

心房と心室の間にあるのが，房室弁（atrioventricular valves)であり，これには，右心房と右心室の 間にある右房室弁 (三尖弁：TRICUSPID VALVE) ${ }^{8}$ および, 左心房と左心室の間にある左房室弁 (二尖弁； 僧帽弁：MITRAL VALVE) ${ }^{(5}$ とがある。

また, 心臟からでる動脈には, 動脈弁 (半月弁：semilunar valves）があり，これには，肺動脈に肺動脈弁 (PULMONARY VALVE) ? , 大動脈に大動脈弁 $(\text { AORTIC VALVE) })^{3}$ がある。

僧帽弁は, 前尖 (AML : anterior mitral leaflet)
と後尖 (PML : posterior mitral leaflet) とからなる が, MeSH 用語には，このような細かい部位の用語は ない。 ${ }^{11)}$

MeSH 用語では，心臟弁（HEART VALVES）と して，上記の 4 つの弁（三尖弁，僧帽弁，肺動脈弁， 大動脈弁）のほかに，三尖弁および僧帽弁を支える乳 頭筋 (PAPILLARY MUSCLES $)^{(6)}$ と腱索(CHORDAE TENDINEAE）をも含んでいる。(図 2 )

表 1. 対象とした MsSH 用語数

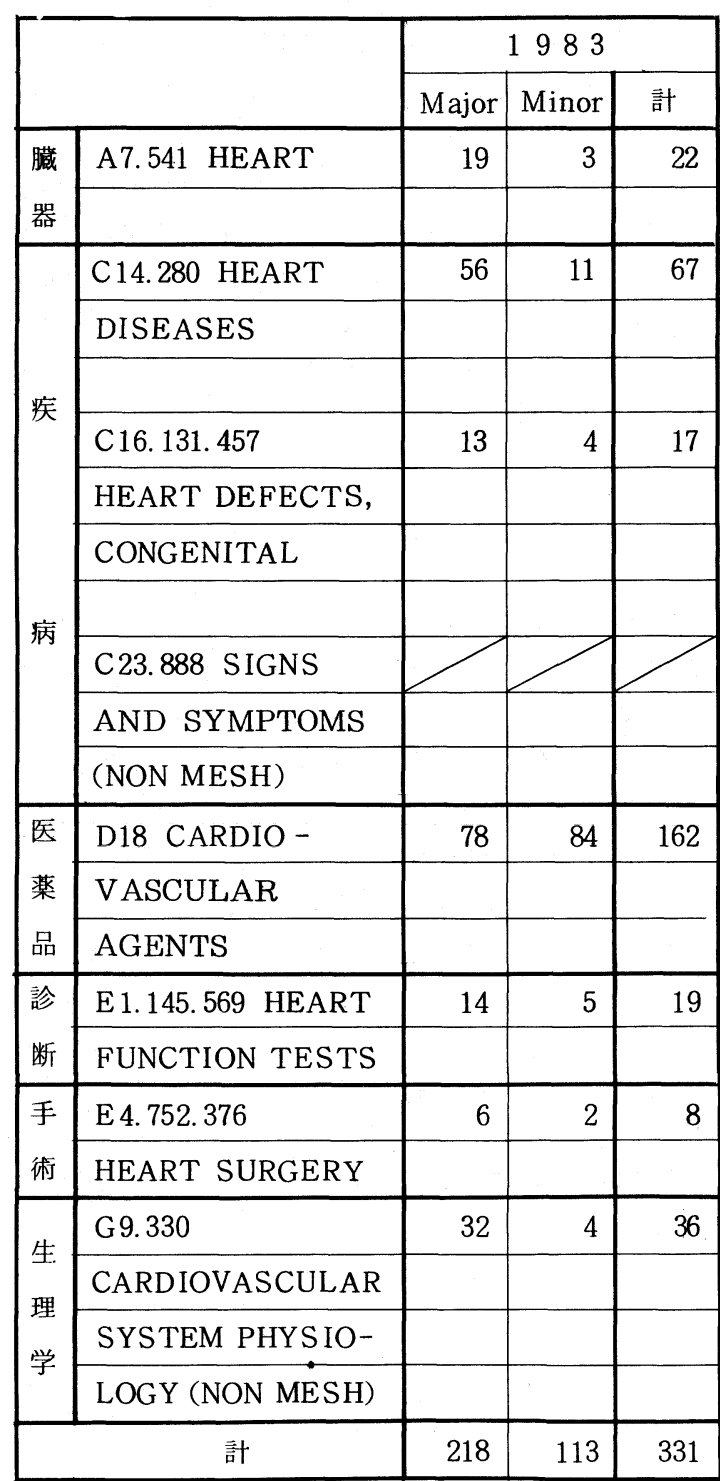




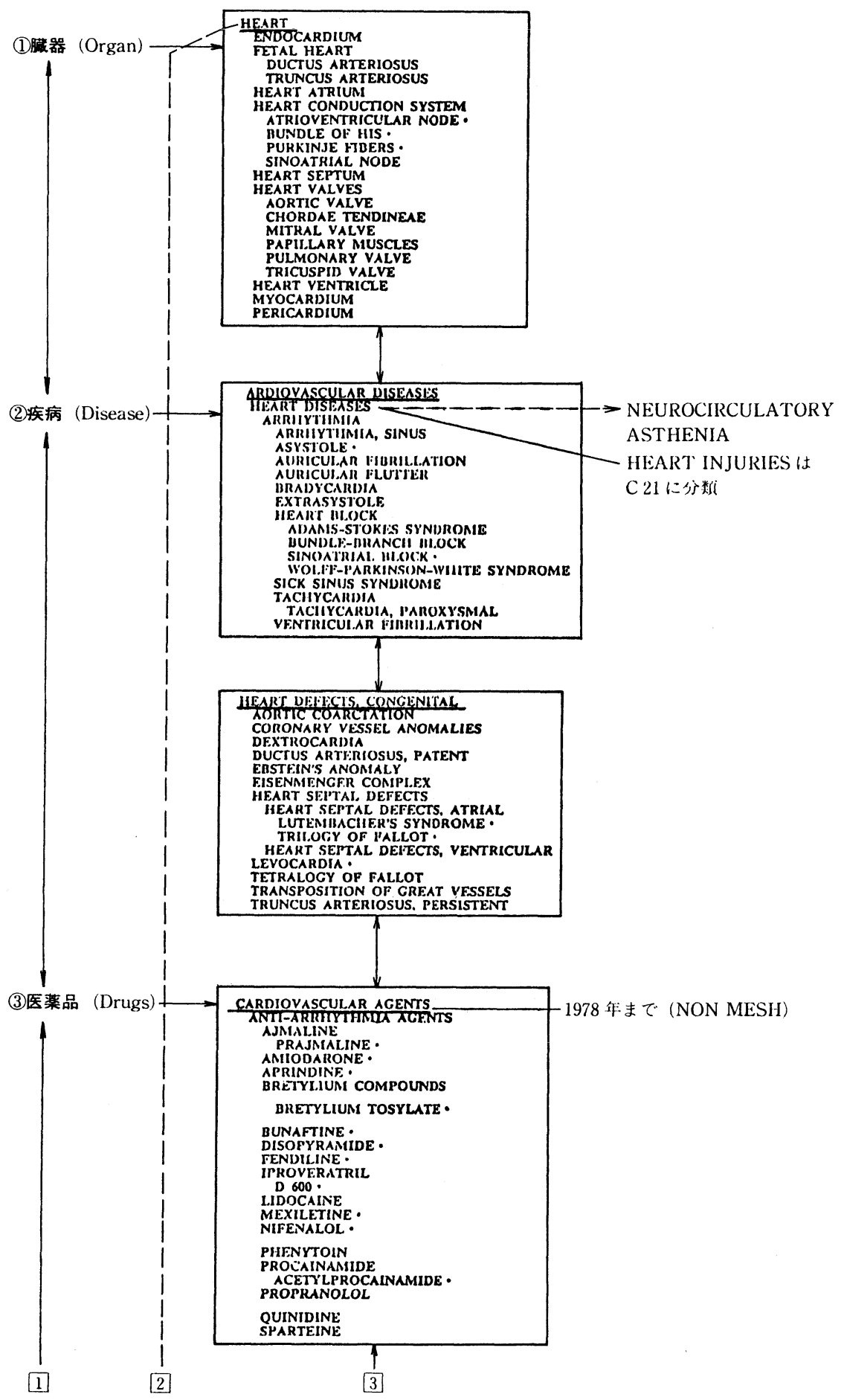

図 1.「ファセット」と心臓に関する MeSH用語 


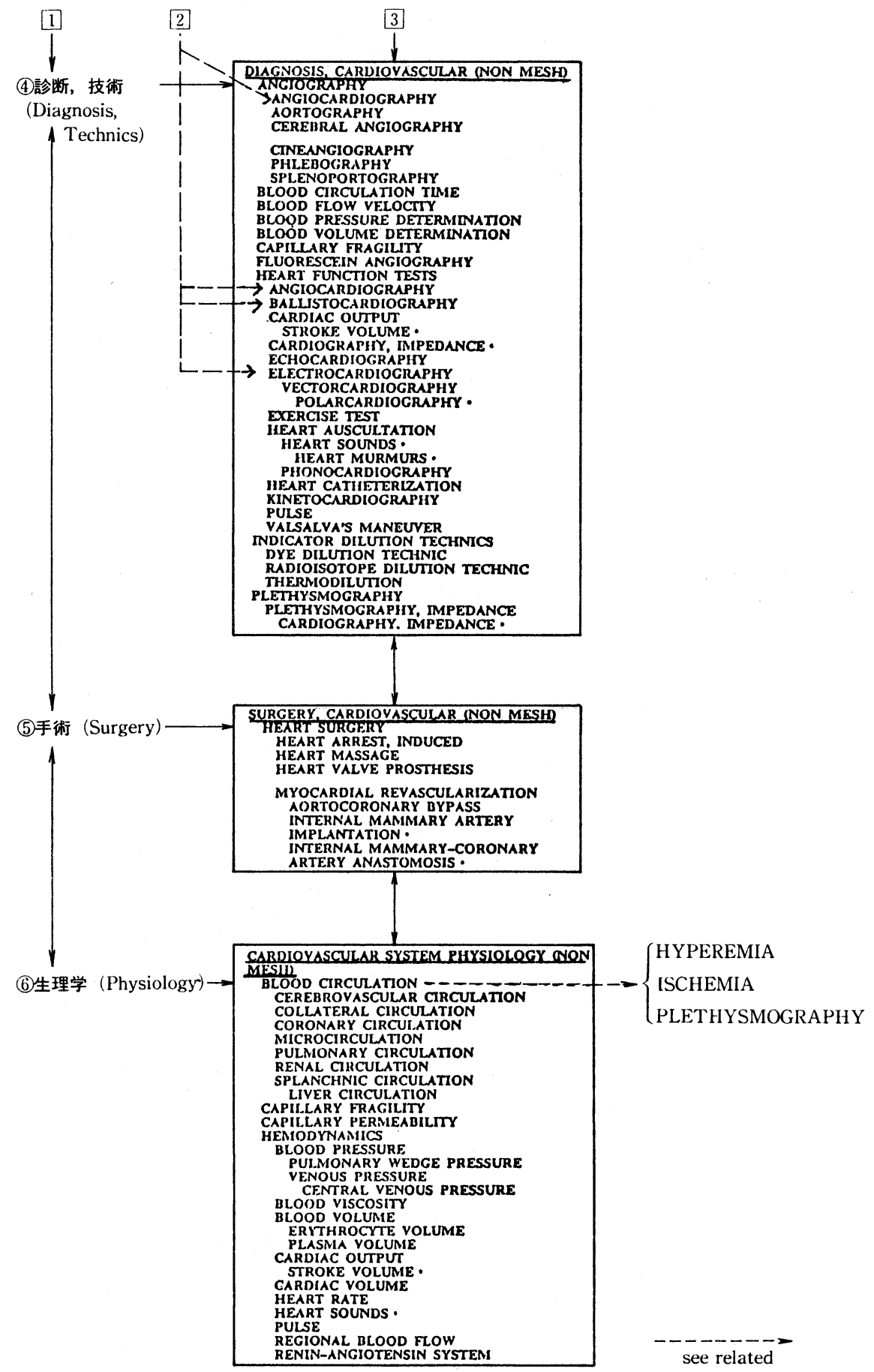

図 1.「ファセット」と心蔵に関する MeSH 用語 
表 2. 心臓の解剖学的 MsSH 用語

\begin{tabular}{|c|c|c|}
\hline 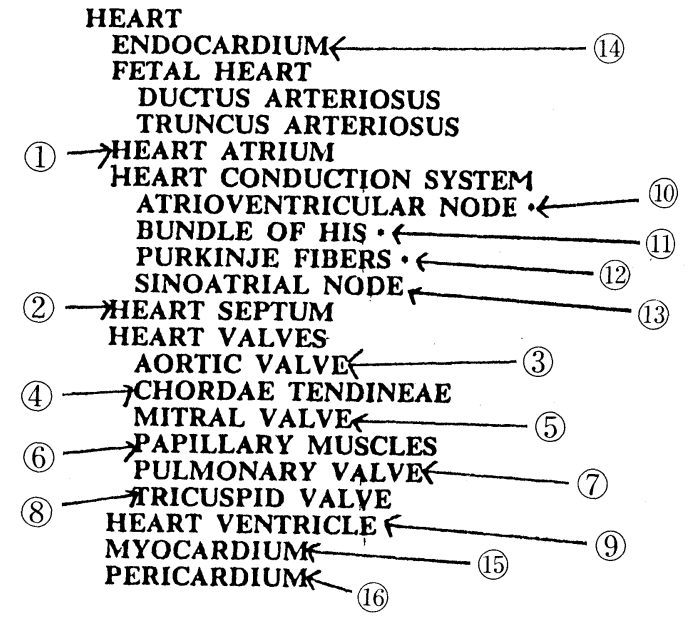 & $\begin{array}{l}\text { A7.541 } \\
\text { A7.541.207 } \\
\text { A7.541.278 } \\
\text { A77.541.278.395 } \\
\text { A7.541.278.930 } \\
\text { A7.541.358 } \\
\text { A77.541.409 } \\
\text { A7.511.409.147 } \\
\text { A7.541.409.273 } \\
\text { A7.541.409.683 } \\
\text { A7.51.409.819 } \\
\text { A7.541.459 } \\
\text { A7.541.510 } \\
\text { A7.541.510.110 } \\
\text { A7.541.510.240 } \\
\text { A7.541.510.507 } \\
\text { A7.541.510.619 } \\
\text { A7.541.510.738 } \\
\text { A7.541.510.893 } \\
\text { A7.541.560 } \\
\text { A7.541.704 } \\
\text { A7.541.795 }\end{array}$ & 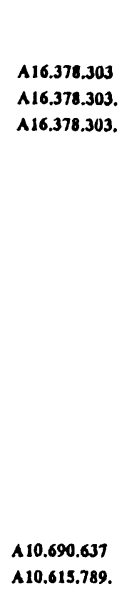 \\
\hline
\end{tabular}

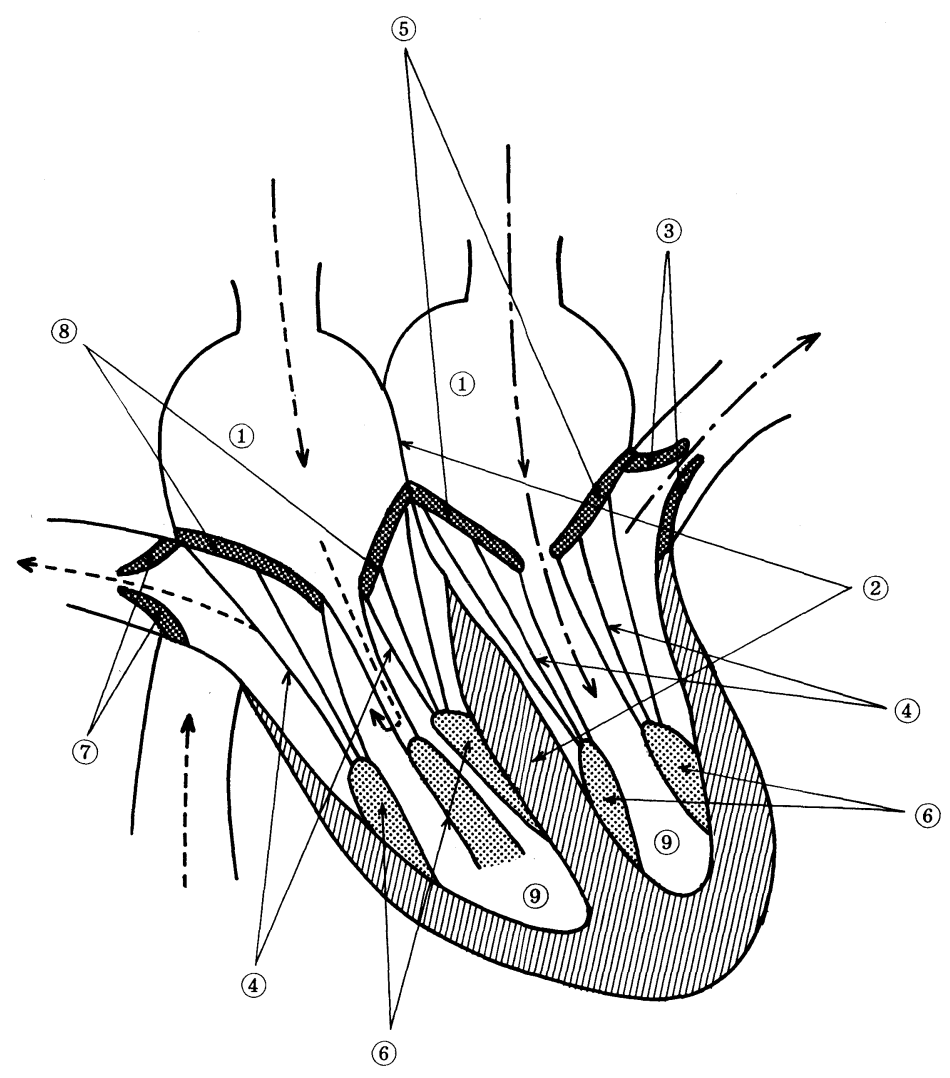

図2，心臓の解剖図 


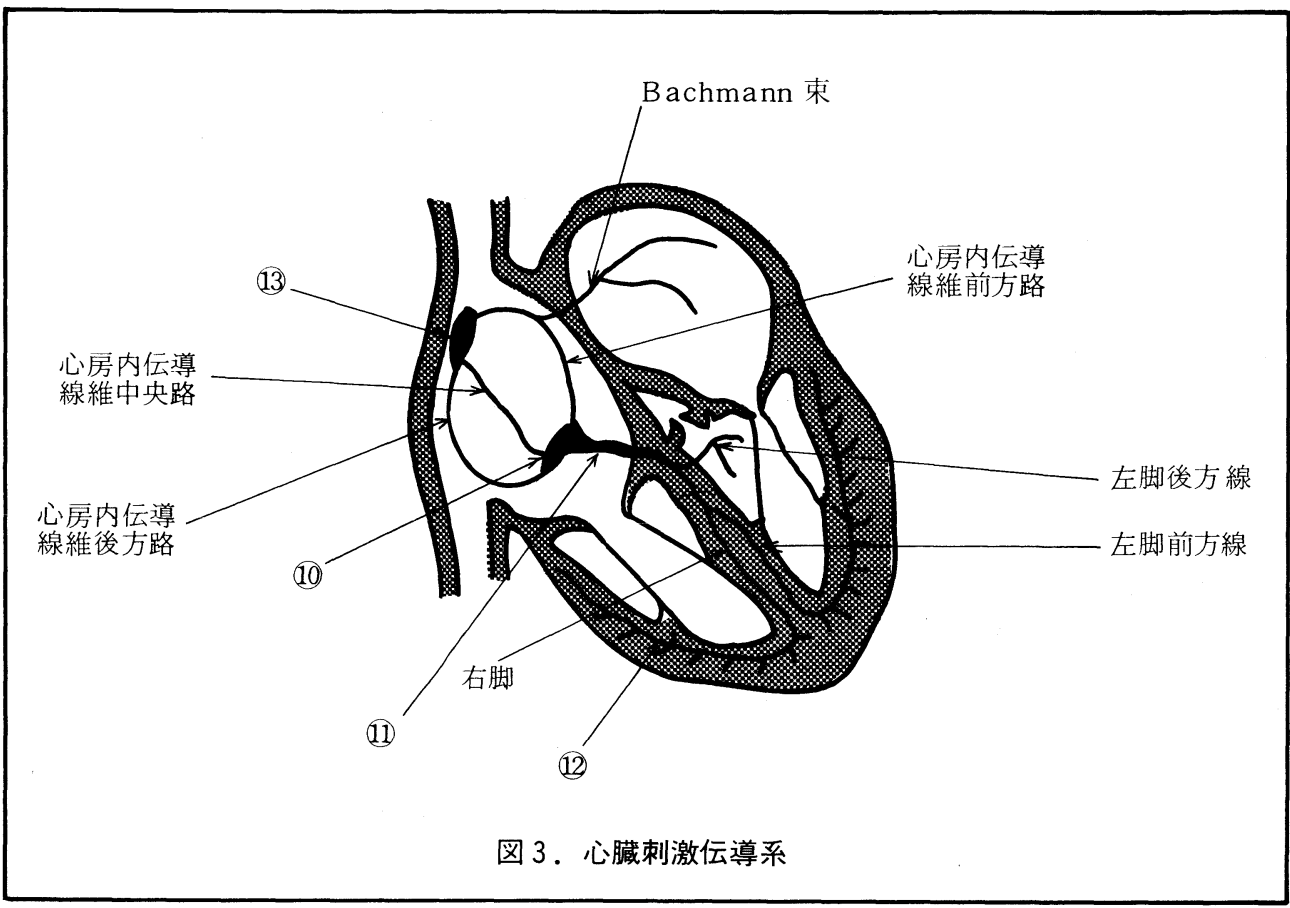

表 3 . 心臟刺激伝導系

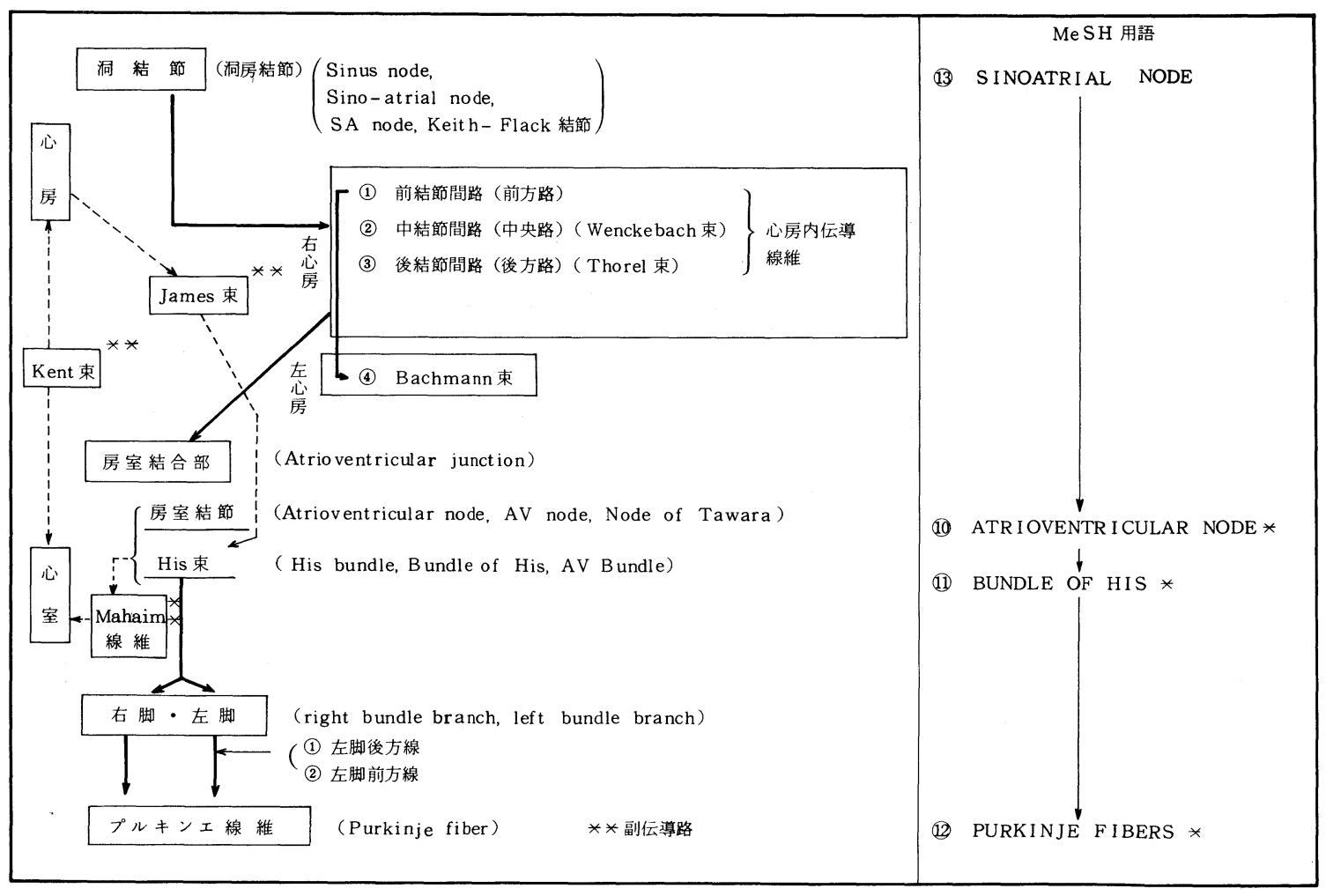




\section{6. 心臟刺激伝導系}

$\mathrm{MeSH}$ 用語の心臓刺激伝導系 (HEART CONDUCTION SYSTEM) は，洞房結節（SINOATRIAL NODE ${ }^{\text {B }}$, 房室結節 (ATRIOVENTRICULAR NODE * ${ }^{\text {(1) }}$ ，ヒス束 (BUNDLE OF HIS * $)^{\text {(1) }}$ ，およびプル キンエ線維 (PURKINJE FIBERS * (1) からなる。こ のうち, 刺激伝導系の源 (pace maker) といえる洞房 結節のみが Major descriptorであり, 他は, Minor descriptorである。

房室結節とヒス束を含めて, 房室接合部 (atrioventricular junction) と呼び'2), 右脚 (right bundle branch) および左脚（left bundle branch）にわかれ るが，それらの MeSH 用語はない。”(図 3，表 3)

\section{7. 心外膜と心膜}

心臓壁は心外膜 (epicardium), 心筋層 (MYOCAR-

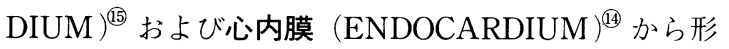
成されるが, $\mathrm{MeSH}$ 用語には epicardium の用語はな

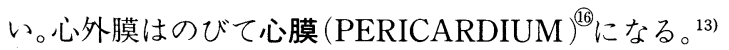
$\mathrm{MeSH}$ 用語では PERICARDIUM を広義に解して, epicardium をPERICARDIUM ${ }^{(1)}$ に含んでいる。つま $\eta, \mathrm{MeSH}$ 用語の心膜 (PERICARDIUM $)^{16}$ は心外膜 (epicardium) でもある。(図 4)

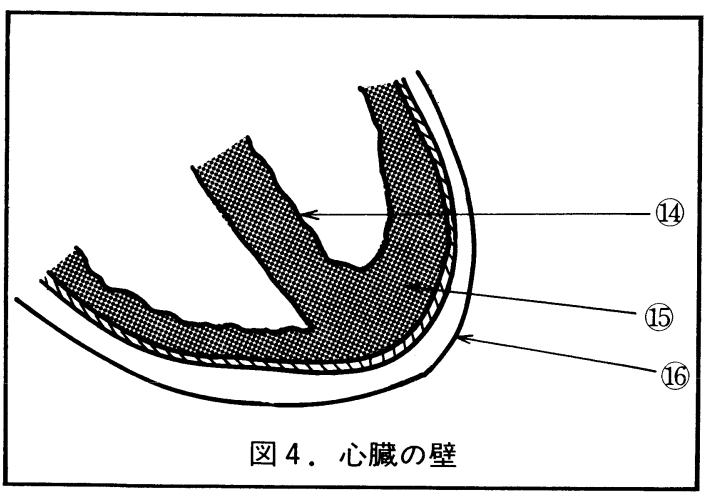

III. 心臟疾患の MeSH 用語

\section{1. 疾患, 障害, 症候群}

Dorlandによると, DISEASE (疾患) を「一連の特 徵的症状を持った一定の病的過程。全身または個々の 部分をおかし, その病因学, 病理学, 予後は既知また は未知」とし，DISORDER (障害)を「機能の混乱ま たは異常。身体的または, 精神的な病的な状態」と説 明している。つまり， disorder は主に機能的混乱をさ
L, MeSH 用語でも MENTAL DISORDERS (精神障 害）のように使用されているが, 疾患のほかに徵候 · 症候に分類されているものも多い。この MENTAL DISORDERS $の \mathrm{MeSH}$ 用語は, C 3 Diseases (疾患) ではなく, F 3 Behavioral and Mental Disordersに 分類されている。(現在, $\operatorname{DISEASE}(\mathrm{S})$ のつく $\mathrm{MeSH}$ 用語は $397, \operatorname{DISORDER}(\mathrm{S})$ のつく $\mathrm{MeSH}$ 用語は 118 ある (Entry term を含む) ) ${ }^{14)}$

また, SYNDROME (症候群)という用語を Dorland では「同時に現われる一連の症状。ある一定の病的状 態におけるすべての徴候」と説明しているが，MeSH 用語では, DISEASE (C 23.280+)の下位概念として 位置づけている。このSyndromeのMeSH用語については 青木の研究 ${ }^{15)}$ がある MeSH 用語としての症候群を調 べる資料としては，「MEDLARS Indexing and Searching Aids $\lrcorner^{16)}$ があるが，これは 10 年以上も前の 1970 年に出版されたものであり，その利用には注意を要す る。また, MeSHのBibliographyである「Jablonski's Illustrated Dictionary of Eponymic Syndromes」 ${ }^{17)}$ 活用することも重要である。

\section{2. 心筋疾患と心臟疾患}

1978 年までは，原発性心筋疾患（MYOCARDIAL DISEASES, PRIMARY) と続発性心筋疾患 (MYOCARDIAL DISEASES, SECONDARY)の MeSH 用

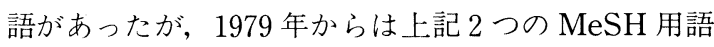
が心筋疾患 (MYOCARDIAL DISEASES) に統一さ れ, 「disease of myocardial tissue」と規定されてい る。この点, 心臟疾患 (HEART DISEASES) が 「diseases of function」であるのと違う。(HEART と MYOCARDIUM との相違については解剖の項で述べ た)

心臟疾患のうち, 先天性心臓奇形 (HEART DEFECTS, CONGENITAL) の MeSH 用語は, C 16. $131+$ 奇形に分類され, HEART DISEASES とは区別 されている。

単行本の件名標目として HEART DISEASESに形 式副標目一一例之ばhandbooksを付与する場合には HEART DISEASES/handbooks とせずに CARDIOLOGY/handbooks とする。(HEART の場合も CARDIOLOGYを使用する)

\section{3. 心房粗動と心室粗動}

一般的に心房の形容詞形は atrial だが，心房細動お よび心房粗動の MeSH 用語では, atrialのかわりに, 
AURICULAR が用いられる。Dorlandによると, auricule (心耳) は「以前は心房を示す言葉として使われた」 とあり，心房細動 (AURICULAR FIBRILLATION), 心房粗動 (AURICULAR FLUTTER) の MeSH 用語 は, atrial の形容詞形がアメリカで一般化する以前に 採用されていたことをしめしている。

また心室粗動（ventricular flutter）の臨床的意味は 心室細動と同様 ${ }^{18}$ だが, MeSH 用語の心室細動 (VENTRICULAR FIBRILLATION)には, 心室粗動 (ventric flutter) は含まれず, 心室粗動にはARRHYTHMIA (IM) + HEART VENTRICLE (NIM) の $\mathrm{MeSH}$ 用語が用いられる。

\section{4. 心蔵拡大と心蔵肥大}

MeSH 用語の HEART ENLARGEMENTは, heart hypertrophy と同義語（準同義語）である。

MeSH 日本語版 (1978)では, HEART ENLARGEMENTの訳語として,「心臓拡大二心腔の拡大」を採 用しているが, これは心蔵肥大の意味でもある。

Dorlandでは, enlargement の項で cardiac enlargementを「代償的機構もしくは, 疾患の二次的効果 による心㵴の拡大, 肥大」とし, また hypertrophyの 項では, ventricular hypertrophy を「心室の心筋の肥 大」としている。

心室肥大 (ventric hypertrophy) には, 解剖学的用 語である HEART VENTRICLEは用いず，HEART ENLARGEMENT が用いられる。

\section{5. 心臟破裂}

心臟破裂の MeSH 用語は, HEART RUPTURE で ある。Annotated MeSHには, 「rupt of any part of heart」と説明があるのみだが, HEART RUPTURE の Scope Noteには, 「Laceration or tearing of the walls of the heart, of the interatrial or interventricular septum, of the papillary muscles or chordae tendineae, or of any of the valves of the heart. Rupture may be due to a variety of pathological entities; however the majority are secondary to myocardial infarction」とある。この Scope Note (以 下規定という）により，心臓破裂の部位には，心藏壁 のほかに, 心房中隔, 心室中隔, 乳頭筋, 腱索および 心臓弁があり，主に心筋梗塞に伴って二次的におこる ものであることがわかる。

僧帽弁逸脱 ${ }^{19220121222) 23)}$ (MITRAL VALVE PROLAPSE)では, 一部の症例において, 逸脱部位の腱索
断裂をおこすことがあるがこの腱索断裂にも HEART RUPTUREの MeSH 用語を用いることに なる。

心臓破裂でも外傷によるものは, 心藏外傷 (HEART INJURIES) の MeSH 用語を用いるが，この用語は， C 14 心臟血管疾患ではなく, C 21 外傷・職業病・中 毒に分類されている。

\section{6. 心蔵弁膜症}

心臟弁膜症 (HEART VALVE DISEASES) は, 閉 塞不全（insufficiency = valves opening too far）およ び狭窄（stenosis= valves not opening enough）とに 区別される。それぞれの弁（II－5参照）に閉塞不全 と狭窄とがあるが, 僧帽弁には, 僧帽弁閉塞不全 (MITRAL VALVE INSUFFICIENCY)，僧帽弁狭 窄（MITRAL VALVE STENOSIS）のほかに，僧帽 弁逸脱 (MITRAL VALVE PROLAPSE) の MeSH 用語がある。この僧帽弁逸脱という $\mathrm{MeSH}$ 用語は, 1979 年に採用され,「Abnormal protrusion of one, or both, of the leaflets of the mitral valve into the left atrium during systole. This may be accompanied by mitral regurgitation, systolic murmur, nonejection click, or cardiac arrhythmia」と規定されている。

また, MeSH 用語では, MITRAL VALVE PROLAPSEの Entry termとして, (1) FLOPPY MITRAL VALVE (2) MITRAL CLICK-MURMUR SYNDROME (3) SYSTOLIC CLICK-MURMUR SYNDROMEを採用しているが,このほかにも表 4 の ような同義語19)がある。

\section{表 4. Mitral value prolapse の同義語}

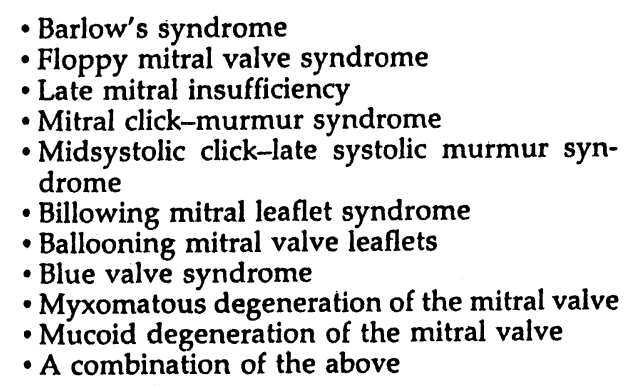

1983 年には, TRICUSPID VALVE PROLAPSE * （三尖弁逸脱）の MeSH 用語が Minor descriptor と して採用され「「Abnormal protrusion of one or more 
of the leaflets of the tricuspid valve into the right atrium during systole」と規定されている。

\section{7. 徵候と症候}

Dorlandによると，徵候（Sign）を「何かの疾患の 存在を表示するもの。検查する医師にわかるような疾 患の客観的証拠。患者の主観的感覚（症候）の反対」 とし，症候（Symptom）を「疾患または患者の主観的 証拠。患者の身体的あるいは精神的状態の変化」とし ている。

MeSH では, SIGNS AND SYMPTOMS (NON MESH）をC 23 Diseases-General Pathology, Signs and Symptomsに分類し, 消化器系 (SIGNS AND SYMPTOMS, DIGESTIVE (NON MESH)) およ び呼吸器系 (SIGNS AND SYMPTOMS, RESPIRATORY (NON MESH)）の徵候・症候のみを1 所 にまとめている。

8. 太鼓ばち指一心臟疾患の徵候・症候の例— 太鼓ばち指とは,「多くの心臟病，とくに先天性心臟 病，僧帽弁疾患，脊椎側弯曲症による心臟疾患，気管 支拡張症, 肺膿瘍, 肺壊疽などの胸部藏器疾患による ところの，手指末端の鼓桴状肥大」24)であるが，MeSH 用語では，この太鼓ばち指 (CLUBBED FINGERS) を, OSTEOARTHROPATHY, SECONDARY HYPERTROPHIC の同義語（準同義語）とみなし, C 5.116 骨疾患およびC 5.550 関節疾患として,心臟 疾患, 胸部臓器疾患の徵候・症候の用語とはしていな い。

\section{IV．心臓のクスリの MeSH 用語}

\section{1.「インデラル」の MeSH 用語}

インデラルは，交感神経べー夕遮断剂として初めて 広く臨床的に応用された高血圧・狭心症・不整脈治療 剂である。

インデラルの剤型には, Tablets $(10 \mathrm{mg}, 20 \mathrm{mg})$ と Injection（2 mg）とがあり，その一般名は，propranolol hydrochloride (塩酸プロプラノロール) であ る。

MeSH 用語でも，PROPRANOROL (図 5 ) は，心 臟血管系薬剤（D 18）としては，ANTI-ARRHYTHMIA AGENTS (抗不整脈剂), ANTIHYPERTENSIVE AGENTS (抗高血圧症剂), VASODILATOR AGENTS（血管拡張剂）に分類されているが,
ベータ遮断剤 (ADRENERGIC BETA RECEPTOR BLOCKADERS) として，自律神経系薬剤（D 16）の 下位概念でもある。

薬物は，その薬理作用からいくつもの概念に分類さ れる可能性があり, Minor descriptor の薬剤について は，その適切な上位概念を知ることが重要である。

\section{2.「アダラート」の MeSH 用語}

アダラート (Adalat) はニフェジピン (Nifedipine) の商品名である。 MeSH 用語の NIFEDIPINE *は Minor descriptor であり，PYRIDINESおよびVASODILATOR AGENTSの下位概念である。MeSH で は, NIFEDIPINE *をPYRIDINESの see under と して記載しているが，狭心症の治療薬としてのアダ ラートには，VASODILATOR AGENTS（血管拡張 薬）の MeSH 用語を用いた方がより適切といえる。 薬物には, 治験名, 一般名, 商品名, 等アクセス・ ポイントが多く,「薬名検索辞典」, $\left.{ }^{25) 「 M e r c k ~ i n d e x ~}\right\lrcorner,{ }^{26)}$ $\ulcorner$ Pharmacological and chemical synonyms $\lrcorner,{ }^{27}$ $\ulcorner$ Chemical abstracts index guide $\lrcorner,{ }^{28)}\ulcorner$ 治験医歯薬情

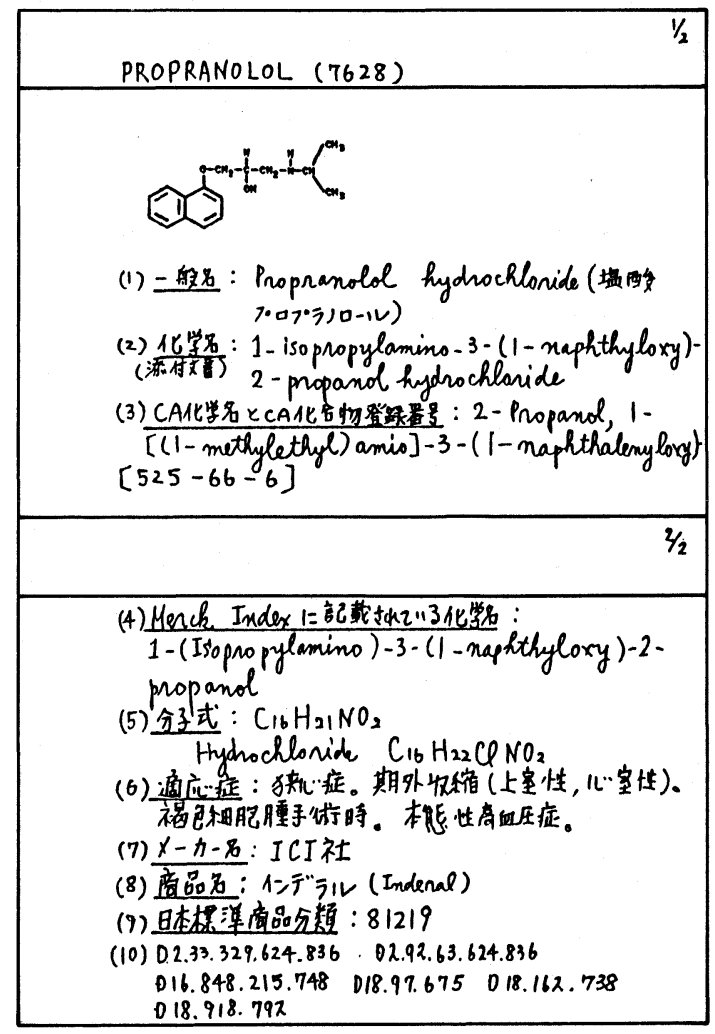

図 5. 医薬品 MeSH 用語情報カード 
報」, 29)「最近の新薬」30)等, 薬名を検索するのに常時使 用するような基本的な参考図書は，図書館にも備之て おくべきだが，図書館と薬剤部（DI 室）との協力体制 を確立しておくことも，また重要である。新薬（ある いは治験薬）に関する情報, 添付文書（能書）あるい はメーカーから提供されるような資料を利用させても らうためにも, 薬剤部の DI 担当者との協力関係が大 切になってくる。

\section{Nitrate と Nitrite}

Dorlandによると, nitrate (nitrāt) (硝酸塩)を、「硝 酸からできる塩の総称。有機硝酸塩は狭心症の治療に 用いられる」とし，nitrite (nitrīt) (亜硝酸塩)を,「有 機亜硝酸塩は狭心症の治療に用いられる」としている。 どちらも有機塩は狭心症の治療に用いられるが, MeSH 用語の NITRATES (硝酸㬈) および NITRITES (亜硝酸塩) は，D1．無機物質に分類されている。 狭心症に用いられる有機硝酸塩はニトログリセリン (Nitroglycerin) であり，有機亚硝酸塩は亜硝酸アミ ル (AMYL NITRITE) である。NITROGLYCERIN は, GLYCERYL TRINITRATE (三硝酸グリセリン) の Entry term であり, AMYL NITRITE と GLYCERYL TRINITRATE がVASODILATOR AGENTS (血管拡張薬) の下位概念である。

\section{V. 心臓の検査の MeSH 用語}

\section{1. 聴診, 心臓聴診, 心音}

一般的に聴診には，心臓聴診をも含むが，MeSH 用 語では，心臟聴診（HEART AUSCULTATION）を 聴診 (AUSCULTATION) と区別している。

「心臟から発生する音は，その持続性が短く，一過 性の場合には心音 heart sound と呼び，より長い場合 には心雑音 heart murmur という」31)が, MeSH 用語で は, 心雑音 (HEART MURMURS *) を心音 (HEART SOUND *) の下位概念としている。すな わち, 心音 (HEART SOUND *) には, 正常心音の ほかに, 心雑音 (HEART MURMURS*)をも含むこ とになる。

また，心臓聴診の下位概念として，心音図法 (PHONOCARDIOGRAPHY) がある。これは,「聴 診を視覚化し, 心臓弁膜症, 先天性心疾患等の診断の ために，心音計を用いて行われるもの」24)だが, MeSH 用語の心臟聴診には, 聴診器を用いて行うもののほか
に，心音計を用いて行う心音図法も含まれることに注 意を要する。

聴診に用いられる聴診器 (stethoscope) の MeSH 用 語としては，AUSCULTATION/instrumentationあ るいはHEART AUSCULTATION/instrumentationを用いるが, 超音波を用いるドップラー聴診器 (Doppler stethoscope) には, AUSCULTATION/ instrumentation + ULTRASONICS/diagnostic use を用いる。

\section{2. 負荷心電図法}

EXERCISE TEST（負荷心電図法）は, 「electrocardiography after measured exercise $\lrcorner$ すなわち, exercise electrocardiography のことであって，いわ ゆる負荷試験（Belastungsproben）全般をさすのでは ない。また,この EXERCISE TEST と HEART FUNCTION TESTS (IM) +EXERTION (NIM) と の相違にも注意を要する。例えば運動負荷後の心電図 について問題にするのではなく，運動と心機能検査と の関係をみる時には, 後者の $\mathrm{MeSH}$ 用語を用いる。

\section{3. 脈波（pulse wave）の MeSH 用語}

「動脈内に起こる圧変動すなわち脈拍は一定の速度 (約 $7 \mathrm{~m} / \mathrm{sec)}$ ) で末梢に伝播される。これを脈波とい う」 $\lrcorner^{24)}$ が, MeSH 用語では, PLETHYSMOGRAPHY (体積変動記録法) および PULSE (脈拍)としている。

\section{4. 心機図法の MeSH 用語}

単行本に件名標目として MeSH 用語を付与すると

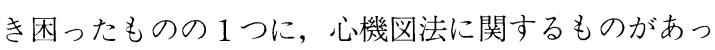
た。

心機図 (mechanocardiography) とは，「心電図に対 比して作られたものであり，心電図が心の電気的活動 をとらえるものであるのに対し，心機図は，心ならび に大血管に関係した機械的現象を曲線としたすべての 記録を包含するものであり，心機図の中には，心音図， 心尖拍動曲線，頸動脈脈波，静脈脈波などが含まれ る」。ำ

$\mathrm{MeSH}$ 用語には，現在では次第に用いられなくなっ てきている(用バリストカルジオグラフィー (drawing of the heart's throwing) (心弾図法) ${ }^{33) 34)}$ (BALLISTOCARDIOGRAPHY)のような検查法の用語はのこって いるが, 心機図のようにそれ自体の MeSH 用語があっ た方が便利だと思われるものがないことがある。(イタ イイタイ病，キノホルムのように) ${ }^{35)}$

そこで, National Library of Medicine Current 
Catalog (NLMCC) では, mechanocardiography (心機図)とい う用語を書名中にもつ単行本に,どのような $\mathrm{MeSH}$ 用 語を付与しているかを調べてみた。この例（図6）

では，KINETOCARDIOGRAPHY の MeSH 用語が 付与されていた。しかし，本来 KINETOCARDIOGRAPHY（胸壁低周波振動図法）とは「前胸壁の心臟 領域に見られる遅い振動を記録する技術で，振動は 胸壁の測定点における心運動の絶対値を表わす」 (Dorland)であり，この $\mathrm{MeSH}$ 用語の付与は正確には 適切でないように思われた。

次に, JOIS-MEDLARSのフリータームでの検索を 利用して, mechanocardiographyにどのような

\section{KINETOCARDIOGRAPHY}

Py, Jean. Phonocardlographle clinique e mécanocardlographle [par] Jean Py [et] Jacques Meurin. Paris, Balliere [1972] 526 p. lllus. 04NLM: WG 141 P995p 1972 Cit. No. 0363151 Price: NA

Sawajama, Toshltaml. Shlnzobyo shlndan no gljutsu ; shinkizu ni yoru. [Dlagnostlc techniques of heart diseases by mechanocardiography, by Toshltaml Sawayama and Isao Niki. Kyoto] Kinpodo [1970] 4, 188 p. Illus. Cover title: Clinical mechanocardlography.

04NLM: WG 141 S271s 1970

Cit. No. 1247537 Price: 9.72

図 6. mechanocardiography（心機図）に対する MeSH 用語(1)（NLMCC による）
$\mathrm{MeSH}$ 用語が付与されているかを調べてみた。その結 果, これには，心機困に含まれる心音図，脈波等の個 別の $\mathrm{MeSH}$ 用語が付与されていた。(図 7)

当館ではまだ具体的に検討しているわけではない が,単行本に自館用の件名標目を付与する場合には, 良 く用いられるような医学用語で $\mathrm{MeSH}$ 用語にないものに ついては，統一的な自館用の件名ファイルを構成して いく必要があるように思う。

羊新内科診断学. 第 4 版 ${ }^{36)}$ ではバリストカルジオグラ フィの記述は削除されている。

5. 血管心臟造影法と心臓カテーテル法 血管心臓造影法 (ANGIOCARDIOGRAPHY) とは 「血管または心腔の 1 つに造影剤を注入して行う心臓 と大血管のX線撮影」(Dorland) であり，心臟カテー テル法 (HEART CATHETERIZATION) とは,「腕, 脚または頸の静脈を通じて，心臓へ，小さなカテーテ 儿を通す。血液試料の採取, 心臓内圧力の測定，心臓 異常の検出が可能になる」(Dorland) である。

ANGIOCARDIOGRAPHY という MeSH 用語は, 1974 年までは, ANGIOGRAPHY の下位概念であり, HEART FUNCTION TESTSの下位概念ではな かった。1975 年に $\mathrm{MeSH}$ の木構造が大幅に変更され た際に, ANGIOCARDIOGRAPHYは, HEART FUNCTION TESTSの下位概念としても位置づけら

[ 3] U: FT: MECHANOCARDIOGRAPHY

S: $\quad 1$ \%?

[4] U: ¥P A

\#0001

$\mathrm{CN}=79016651$

$T I=$ [ADVANCES IN NON-INVASIVE PROCEDURES TO DIAGNOSE ACQUIRED AND CONGENITAL CARDIAC VALVULAR DISEASE (AUTHOR'S TRANSL)]

$A U=$ KUHN $P$

$J N=0043-5325$ WIEN KLIN WOCHENSCHR

$\mathrm{VN}=$ VOL. 90 NO. 16 PAGE. 585-94'78

$\mathrm{Cl}=(\mathrm{DE} \quad$ ) (AUT) $($ )

$\mathrm{KW}=$ AORTIC VALVE INSUFFICIENCY/DIAGNOSIS; AORTIC VALVE STENOSIS/DIAGNOSIS; CAROTID ARTERIES; ECHOCARDIOGRAPHY; ELECTROCARDIOGRAPHY; ENGLISH ABSTRACT; *HEART DEFECTS, CONGENITAL/DIAGNOSIS; *HEART DISEASES/DIAGNOSIS; HUMAN; IDIOPATHIC HYPERTROPHIC SUBVALVULAR STENOSIS/DIAGNOSIS; METHODS; MITRAL VALVE INSUFFICIENCY/DIAGNOSIS; MITRAL VALVE STENOSIS/DIAGNOSIS; PERICARDIAL EFFUSION/DIAGNOSIS; PHONOCARDIOGRAPHY; PULSE

図 7.Mechanocardiography（心機図）に対するMeSH 用語(2)（JOIS-MEDLARSによる） 
れた。

逆に, 以前は, HEART FUNCTION TESTS の下 位概念だったものが，HEART FUNCTION TESTS とはみなされなくなったものもある。(1)DYE DILUTION TECHNIC (色素希釈法) (2) ELECTROKYMOGRAPHY（エレクトロキモグラフィー）およ び(3) RADIOISOTOPE DILUTION TECHNIC (放射 性同位元素希釈法) がそれである。このうち，DYE DILUTION TECHNICおよびRADIOISOTOPE DILUTION TECHNIC は, INDICATOR DILUTION TECHNICS (標識希釈法) の下位概念として, 心臓血管系の診断の用語としてのこったが, ELECTROKYMOGRAPHY (心藏や他の動く藏器の動き をX線で見る方法) (Dorland) は, ELECTRODIAGNOSIS, KYMOGRAPHY およびRADIOGRAPHY の下位概念として位置づけられ，心臟血管 系の診断の用語ではなくなった。

6.Mモード心エコー図と断層心エコー図

心臓の超音波検査法には，ブラウン管への表示法の 相違により，Mモード心エコー図（Mモード法）と超 音波心臓断層図 (断層心エコー困, $\mathrm{B}$ モード法) とが ある。

M モード心ェコー図 ultrasound cardiography (UCG) は，米国では echocardiography といい，現 在ではBモード法と区別するために，M-mode echocardiographyと呼ばれている。

断層心エコー図は, 米国では当初cardiac ultrasonography と呼ばれていたが, 現在ではMモード法 と区別するために， cross-sectional echocardiographyまたは two-dimensional echocardiography と呼ばれている。

MeSH 用語の ECHOCARDIOGRAPHY は「Use of ultrasonic reflection or echo from the interfaces of the heart for the diagnosis of heart disease $\lrcorner$ と規 定されており，Mモード心エコー罒と断層心エコー 図を含む。

\section{VI. 心蔵外科の MeSH 用語}

\section{HEART SURGERY と HEART/surgery}

副標目の surgeryは, CategoryAの用語と一緒に使 用できるが, HEART/surgery という使われかたは原 則的にしない。これはHEART SURGERY という
$\mathrm{MeSH}$ 用語が別にあるからである。DISEASE/drug therapyにDRUG THERARY が使用されるのと同 様である。

\section{2. 外科と外科手術}

外科（SURGERY）は，G2医療衛生業務に分類さ れる用語で, SPECIALTIES，SURGICAL(外科専門 分野）の一部門（the field of surgery as a surgical specialty）をなすものである。外科手術（SURGERY， OPERATIVE) は，E4外科手術の見出し語となる用 語で, 臟器あるいは疾患に対応するものである。1979 年までSURGERY は SPECIALTIES, MEDICALの 一部門とされていたが, 1980 年から G2. 403.776+の 木構造に変更があり, SPECIALTIES, OTHER(NON MESH）およびSPECIALTIES，SURGICAL の MeSH 用語が採用され，外科は外科専門分野の一部門と なった。

外科手術の歴史に関するものは, SURGERY, OPERATIVE/history とせずに, SURGERY/historyに索 引される。

\section{3. 外科用機器と外科用器具}

外科用機器 (SURGICAL EQUIPMENT) と外科用 器具（SURGICAL INSTRUMENTATION）とは, その大きさを基準に区別され，器具は手でもてる大き さのものをいう。

心藏外科に用いる全ての器具には HEART SURGERY/instrumentation + SURGICAL INSTRUMENTATIONS $の \mathrm{MeSH}$ 用語を用いる。

\section{4. 人工心臓と人工心肺装置}

HEART, ARTIFICIAL と HEART, MECHANICAL という MeSH 用語がある。この artificial と mechanical という言葉の区別を理解しておく必要が ある。Annotated MeSH によると, HEART, ARTIFICIAL (人工心臟) は「implanted pump replacing whole or part of heart」とし, HEART, MECHANICAL（人工心肺装置）は「external heart-lung machine」と説明している。

HEART, ARTIFICIAL およびHEART, MECHANICAL とも, 人工臟器 (ARTIFICIAL ORGANS)の下位概念であるが, HEART, ARTIFICIAL は, PROSTHESIS (人工器官) の下位概念でもある。 つまり，HEART, MECHANICAL は心臟手術で用い られる体外循環装置をいう。

NLMC (National Library of Medicine Classifica- 
tion)では, HEART, ARTIFICIAL および HEART, MECHANICAL ともWG 169.5 に分類している。

なお，心臓移植に関するものは，HEART/transplantationに索引される。

\section{5. 凍結外科と冷却低体温法}

$\mathrm{MeSH}$ 用語の CRYOGENIC SURGERY (凍結外 科)は，E4外科手術に分類される用語であり，HYPOTHERMIA, INDUCED (冷却低体温法) は, E3 麻 酔と無痛法に分類される用語である。CRYOGENIC SURGERY は 「destruction of tissue by very low temp」とされ, HYPOTHERMIA, INDUCED は $\ulcorner$ cooling of organs during surgery」とされている。

また， CRYOTHERAPY という MeSH 用語もある が，これは，E2治療に分類される用語であり， COLD/therapeutic use と区別する必要がある。 COLD/therapeutic use は, ねんざの治療に COLD (冷 温）を用いるときなどに使用され，CRYOTHERAPY はそれより低い温度を用いた治療をいう。

\section{VII. 心蔵の生理の MeSH 用語}

\section{1. 生理学的用語の位置}

$\mathrm{MeSH}$ の中で生理学的用語は, G Biological Sciencesに, 生理学一般 $(\mathrm{G} 7)$, 生殖と尿生殖の生理学 $(\mathrm{G}$ $8)$, 循環と呼吸の生理学 (G9), 消化, 口腔および 皮虞の生理学 (G10), 筋骨格, 神経および眼の生理学

(G11) の項目があり，心臟の生理学的用語はG9. 330 十循環器系の生理学として1 カ所にまとめられてい る。

また, 器官に関する生理や病態生理（pathologic physiology)に関しては, 副件名の physiology および physiopathology を考慮しなければならない。副件名 の規定は MeSHの Introductionに述べられている が，その使い方に慣れるために，副件名の使用概念を 目録カードに転記して活用するのも一方法であ万 j。 ${ }^{37)}$

\section{2. 心拍出量と心臓容積}

$\mathrm{MeSH}$ 用語では，心拍出量 (CARDIAC OUTPUT) を 1 回拍出量 (STROKE VOLUME *) の上位概念と L, STROKE VOLUME * をVENTRICULAR EJECTION FRACTION (心室駆出分画)の同義語 (準 同義語) としている。

また，心臓容積 (CARDIAC VOLUME) を MeSH
用語では，「The volume of the heart, determined by a variety of technics, and usually relating to the volume of blood contained with it at various periods of the cardiac cycle; includes total cardiac volume, left ventricular diastolic and end diastolic volume, atrial volume, and stroke volume」と規定している。 すなわち，CARDIAC VOLUMEは，心藏周期 (cardiac cycle) における心臓内の血液量にあって, 1 回拍出量 (stroke volume) に伴う心臟内の血液量も 心臓容積に含んでいる。心臓内の血液量については CARDIAC VOLUME を，心臟からの拍出量について は CARDIAC OUTPUTを用いることになる。

また, CARDIAC OUTPUT, LOW の MeSH 用語 が 1980 年に採用された。この用語は, 「A state of subnormal or depressed cardiac output, usually seen in patients with heart failure secondary to coronary artery, hypertensive, primary myocardial, valvular or pericardial disease」と規定され, low cardiac output syndrome と同義語（準同義語）であって，生 理学的用語ではない。

\section{VIII. おわりに}

著者が MeSH 用語を系統別・体系的に学習している のは, MeSH 用語の理解 (Scope Notes の理解) を通 して, 医学図書館員 (Health Science Librarian) と して必要な医学の基礎知識を吸収するためである。

$\mathrm{MeSH}$ 用語を学習しはじめたきっかけは， 5 年前に 本学で開講されている「医療従事者養成カリキュラ ム」38)を受講したことにあった。当時, 単行本係として 医学書に件名標目を付与していたので，医学図書館員の立 場で医学用語 (MeSH 用語) をマスターし，実務に役 立てたいという気持があった。この意味で，上記の力 リキュラムに参加できたことは非常に幸いであった。 最近とくに感じることだが, 医学図書館（室）員と して, 最低限の基礎的な医学知識を吸収しておくこと はもちろん必要だが, そのほかに, 有機化学や薬学等 の基礎知識もある程度身につけておくべきではないか と思う。専門的に詳しいことは無理としても, 有機化 合物命名法, 分子式, 構造式等の概論的なことは, 一 応知っておく必要があろう。参考係として, JOIS 等の 機械検索を担当している者にとっては，デー夕・ベー 又 (CAS ONLINE 等) 毎に, 一般的な医学図書館員 
とは違ったより専門的な知識を要求されることと思 う。これらの知識をどの程度まで吸収すべきかは，そ の図書館（室）の機械検索に対する政策にもよるが, 基本的には，para-medical staff が持つぐらいの基礎 知識は吸収しておく必要があるのではないかと思って いる。

西岡によると,39犰誌の評価・選択も図書館員が行う べきとのことだが，現在，著者の業務の一つである「洋 書の選択」のための資料として, Book Reviewsに目を 通すことにも, MeSH 用語の学習は大いに役立ってい る。

また，最近，佐々木の論文㔀を読んで感じたことだ が, MeSH 用語の学習も「ドクメンテーションとして のターミノロジー」の側面も考慮していかねばならな いと思う。

八ード，ソフトがますます進む図書館コンピュータ 化のあらしの中で, シソーラスとしての $\mathrm{MeSH}$ 用語が 今後どのような形をとるかは定かでないが, 21 世紀の Health Science Library で生き残れるような Health Science Librarianを目指したいと思う。

\section{引用 文 献}

1) Medical Subject Headings (1983). (pt. 2 , January Index Medicus)

2）川野惟二：MeSH(シソーラス第 7 回)。情報管理, $20(7): 577-591,1977$.

3 ）シソーラス入門 (NIPDOKシリーズ13)。東京，日 本ドクメンテーション協会, 1970. MeSH：p. $34-47$.

4）堀江幸司：病院図書室員に必要な医学知識の効果 的な学び方. 近畿病院図書室協議会会報，8（5）: 27-29, 1982 .

5 ）堀江幸司：MeSH の系統別・体系的学習一心臟血 管系の MeSH を中心として一。医学図書館, 26(4) : 173-181, 1979.

6 ) 堀江幸司：消化器系MeSHの体系的学習一目でみ る消化器系の MeSH一。医学図書館, 29(2)： 135-148, 1982.

7 ) Technical Notes-MEDLARS Indexing Instructions (1975).

8 ) Dorland's Illustrated medical dictionary. 25 th ed. Philadelphia, Saunders, 1974.

9 ) ドーランド図説医学大辞典。原書 25 版。東京, 廣
川書店, 1980 .

10) * Dorland's Illustrated medical dictionary. 26 th ed. Philadelphia, Saunders, 1981.

11） MEDLARSトレーニング・シラバスーオンライン 検索のために一。東京, 国際医学情報センタ一, 1978. MEDLARS 検索の限界. p.52.

12）前田如矢：心電図の学び方. 東京, 金芳堂, 1982.

13）山本敏行：新しい解剖生理学. 第 6 版. 東京, 南 江堂, 1974. p.134.

14) Permuted Medical Subject Headings (1983).

15）青木仕：Syndrome (症候群)の Index Medicus·医 学中央雑誌及び MEDLARS 文献検索による分 析. 第 14 回医学図書館員研究集会, 357-368, 1980.

16) MEDLARS Indexing and Searching Aids (1972).

17) * Illustrated dictionary of eponymic syndromes and diseases and their synonyms. Philadelphia, Saunders, 1969.

18）五十嵐正男：不整脈の診かたと治療。第 3 版。東 京, 医学書院, 1977. p.205.

19) Mitral valve prolapse syndrome. In Quick reference to cardiovascular diseases. 2nd ed. 〔Ed. by] E. K. Chung. Philadelphia, Lippincott, 1983. Chapter 14. p.222-231.

20) Chung, E. K. : 心臟病クイックリファレンス(博 定監訳）東京，医学書院，1981. 僧帽弁逸脱症候 群. p. 60-65.

21）石川恭三：新心臟病学. 東京, 医学書院, 1979. 僧帽弁逸脱症候群（クリック一収縮後期雑音症 候群) Prolapsed mitral leaflet syndrome. p. 334-335.

22）町井 潔：断層心エコ一図. 東京, 中外医学社, 1981. 僧帽弁逸脱．p. 102-106.

23) Jeresaty, R. M. : Mitral valve prolapse. New York, Raven Press, 1979.

24）医学大辞典．第 16 版。東京，南山堂， 1978 .

25）薬名検索辞典 -1981 。東京，薬業時報社， 1981 .

26) * Windholz, M. : The Merck index : an encyclopedia of chemicals and drugs. 9th ed. Rahway, N. J., Merck, 1976.

27) * Marler, E. E. J. : Pharmacological and chemical synonyms. 7 th ed. Amsterdam, Excerpta Medica, 1983

28) * Chemical Abstracts Service:Chemical Ab- 
stract : index guide, 1977-1981. Columbus, Ohio, American Chemical Society, 1982.

29）治験医歯薬情報（診療と新薬別冊）。東京, 医事出 版社, 1982 .

30）最近の新薬．東京，薬事日報社， 1982 .

31）藤田拓男：必修内科学. 東京, 南江堂, 1979. p. 176.

32）稲垣義明：循環器疾患の非侵襲的検査. 東京, 朝 倉書店, 1982. p. 199.

33）笹本 浩：バリストカルヂオグラフィー心弾困法. 東京, 医学書院, 1955.

34）吉利 和：新内科診断学. 第 3 版. 東京, 金芳堂, 1978. p. 378 .

35) 後藤敬治：MEDLARS：入力の技術的問題一 1 . 入力作業のあらまし, 入力対象雑誌と論文, 作業 用 tool 類および索引作成者について一. 医学図書 館, 19(1)：35-54, 1972.
36）吉利 和：新内科診断学. 改訂 4 版. 東京, 金芳 堂, 1980

37）小川晋平：MeSH subheadings list の辞書体編成 の試み。医学図書館, $23(3): 155-160,1976$.

38）大井 晴：東京女子医科大学図書館における亿 ン・サービス・トレーニングについての最近の事 例一特に医学知識の習得について一. 医学図書館, $19(4)$ : 339-342, 1972.

39）西岡正行：医学図書館における雑誌の選択・評価. 医学図書館, 28 (4)：268-282，1981.

40）佐々木肇：ドキュメンテーションのターミノロ ジー。ドクメンテーション研究, 32(11)：547-550, 1982.

(*：MeSH の Bibliography であることを示す)

\section{医学洋書総合目録}

1977 年 年間累積版 15,000 円（含送料）

1980 年 年間累積版 20,000 円（"

第 17 回医学図書館員研究集会論文集

テーマ：学術情報と医学図書館 19837,500 円(含送料)

\section{第 9 回医学図書館員セミナ一論文集}

テーマ：医学図書館における二次情報サービス 1983 6,500 円

相互貸借マニュアル 改訂版 1983 2,500 円

（含送料）

\section{現行医学雑誌所在目録 $1983 \quad 6,600$ 円(含送料)}

発行所

干 113 東京都文京区弥生 $2-4-16$ 学会センタービル内

\section{日本医学図書館協会}

Tel：03-815-1942 郵便振替 東京 6-49585 